\title{
HEALTH AND SAFETY IN MAINTENANCE ACTIVITIES
}

\author{
UNGUREANU Nicolae Stelian
}

Faculty of Engineering, Department of Engineering and Management of Technology, Technical University of Cluj Napoca, North University Center of Baia Mare, Baia Mare, Romania, nicolae.ungureamu@cunbm.utcluj.ro

\section{DARABA Dinu}

Faculty of Engineering, Department of Engineering and Management of Technology, Technical University of Cluj Napoca, North University Center of Baia Mare, Baia Mare, Romania, daraba.dinu@cunbm.utcluj.ro

\section{MORARU Roland Iosif \\ Department of Mining Engineering, Surveying and Civil Engineering, Faculty of Mining Engineering, University of Petrosani, Petrosani, Romania, roland_moraru@yahoo.com}

\begin{abstract}
The paper examines some aspects of health and safety at work in maintenance activities. It was analysed the occurrence of accidents, statistically, in maintenance work. There have been identified a number of causes of accidents and there have been proposed some measures to reduce them.
\end{abstract}

Key words: maintenance, health, safety, management

\section{Introduction}

Maintainability is the ability of a machine or equipment, in default usage conditions, to be maintained, or restored, in the state to meet the specified functions when maintenance actions are carried out under conditions specified in a given time, with procedures and remedies prescript.

Maintenance consists in all necessary management and technical actions carried out in order to maintain or restore the function or functions of a system. The main maintenance systems are shown in Figure 1.

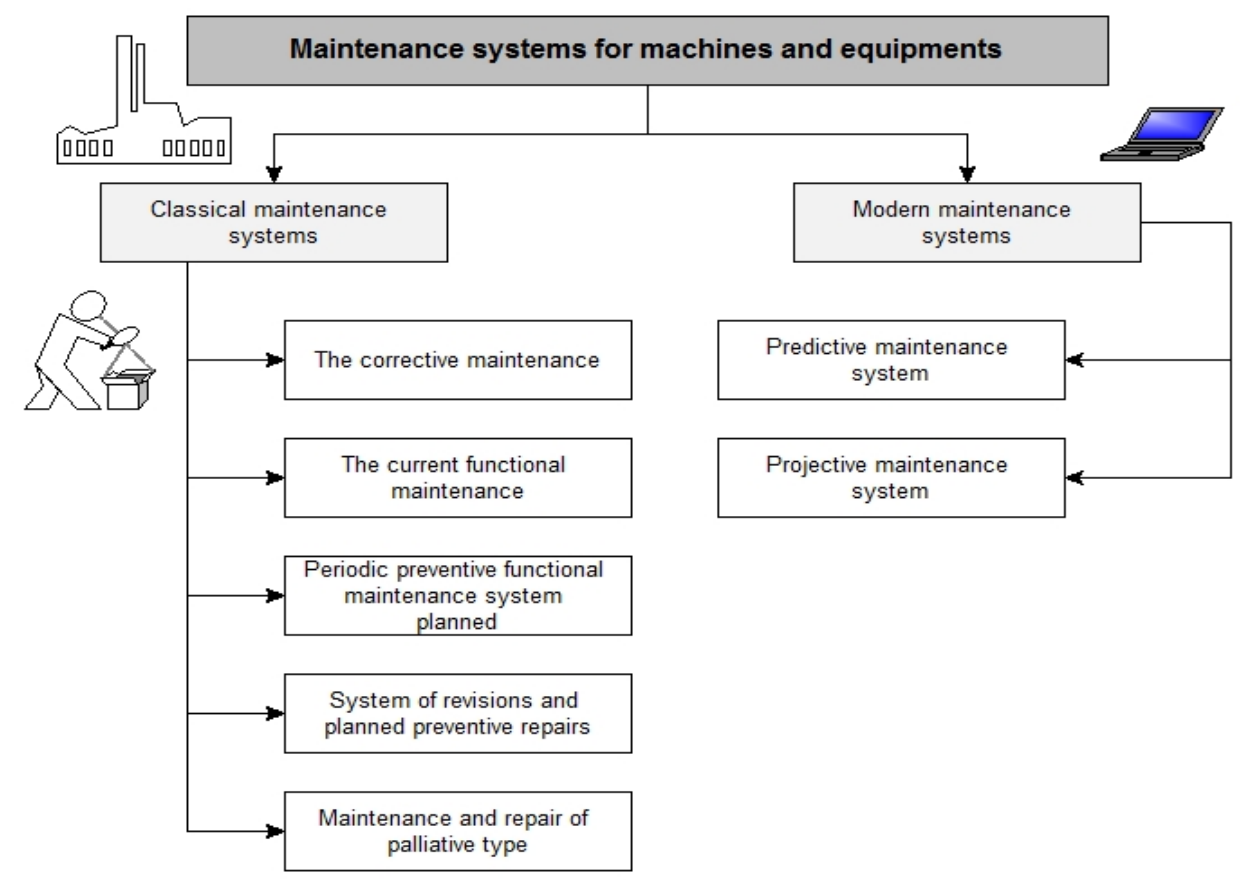

Figure 1: Maintenance systems for machines and equipments

On managerial, technical or economic considerations each company chooses a maintenance system (or in a few cases even more maintenance systems) which it will be apply. But regardless of the 
type maintenance system chosen, it will influence the health and security in the company. First a maintenance system chosen bad or applied with low efficiency leads to lower performance of machinery and equipment. This means lower technically performances and also lower health and safety performances for operators. Secondly, the maintenance work itself must be conducted under safe conditions for maintenance workers and for other participants in the maintenance process. (example: machine operators, designers, experts, etc.). The question is if the maintenance is an activity more dangerous than others and the answer to this question can only be given by statistical analysis.

\section{Statistical analysis for maintenance work}

Statistical analysis for maintenance work in Romania, was done by using public data provided by the National Statistics Institute. [2]. But here is a problem: the maintenance activities covers an extremely broad range of fields, from engineering or extractive industries, through storage and transport, to household area. Thus it is very difficult to assess the number of workers involved in maintenance activities. Data from France and Spain indicate that about 6\% of the working population is involved in maintenance activities [3]. In Romania the statistical situation for the employed population is shown in Table 1.

Table 1: The employed population by activities of national economy at level of CAEN section

\begin{tabular}{|c|c|c|c|c|c|c|}
\hline \multirow{3}{*}{$\begin{array}{l}\text { CAEN Rev.2 (activities of } \\
\text { national economy) }\end{array}$} & \multicolumn{6}{|c|}{ Years } \\
\hline & 2008 & 2009 & 2010 & 2011 & 2012 & 2013 \\
\hline & \multicolumn{6}{|c|}{ Measure unit thousands persons } \\
\hline TOTAL & 8747 & 8410,7 & 8371,3 & 8365,5 & 8569,6 & 8530,6 \\
\hline B Extractive industries & 81,4 & 73,2 & 65,4 & 64,8 & 65,2 & 63,3 \\
\hline C Manufacturing industries & 1691 & 1490,8 & 1471,9 & 1495 & 1508,8 & 1531,8 \\
\hline H Transport and storage & 422 & 418,9 & 425,8 & 434 & 446,8 & 429,6 \\
\hline $\begin{array}{l}\text { M Professional, scientific } \\
\text { and technical activities }\end{array}$ & 165,9 & 164,3 & 155,9 & 161,1 & 165,9 & 169,1 \\
\hline N Support services & 217 & 207,4 & 203,7 & 227,9 & 258,2 & 271,2 \\
\hline S Other service activities & 120,4 & 141,2 & 150,4 & 129,8 & 167,4 & 162 \\
\hline
\end{tabular}

Based on the authors' professional experience have made several assumptions regarding the number of workers involved in maintenance activities in the industrial fields presented in Table 1 . The results are shown in Table 2

Table 2: The workers involved in maintenance

\begin{tabular}{|c|c|c|c|c|c|c|c|}
\hline \multirow{2}{*}{$\begin{array}{c}\text { CAEN Rev.2 (activities of } \\
\text { national economy) }\end{array}$} & \multicolumn{7}{|c|}{ Years } \\
\cline { 2 - 8 } & $\mathbf{2 0 0 8}$ & $\mathbf{2 0 0 9}$ & $\mathbf{2 0 1 0}$ & $\mathbf{2 0 1 1}$ & $\mathbf{2 0 1 2}$ & $\mathbf{2 0 1 3}$ \\
\cline { 2 - 8 } & \multicolumn{7}{|c|}{ Measure unit thousands persons } \\
\hline $\begin{array}{c}\text { TOTAL employed } \\
\text { population }\end{array}$ & 8747 & 8410,7 & 8371,3 & 8365,5 & 8569,6 & 8530,6 \\
\hline B Extractive industries 20\% & 16,28 & 16,64 & 13,08 & 12,96 & $13.9 p r$ & 12,66 \\
\hline $\begin{array}{c}\text { C Manufacturing industries } \\
\mathbf{1 5 \%}\end{array}$ & 253,65 & 223,62 & 220,785 & 224,25 & 226,32 & 229,77 \\
\hline $\begin{array}{c}\text { H Transport and storage } \\
\mathbf{1 5 \%}\end{array}$ & 63,3 & 62,835 & 63,87 & 65,1 & 67,02 & 64,44 \\
\hline $\begin{array}{c}\text { M Professional, scientific } \\
\text { and technical activities 10\% }\end{array}$ & 16,59 & 16,43 & 15,59 & 16,11 & 16,59 & 16,91 \\
\hline N Support services & 217 & 207,4 & 203,7 & 227,9 & 258,2 & 271,2 \\
\hline S Other service activities & 120,4 & 141,2 & 150,4 & 129,8 & 167,4 & 162 \\
\hline Total maintenance workers & 687,22 & 668,125 & 667,425 & 676,12 & 748,57 & 756,98 \\
\hline Total maintenance \% & 7,86 & 7,94 & 7,97 & 8,08 & 8,74 & 8,87 \\
\hline
\end{tabular}

The next step is the statistical analysis of work accidents in the field of maintenance activities. Following the same procedure as for determining the number of workers involved in maintenance activities and the same sources of data were obtained the values shown in Table 3 and 4. 
Table 3: Accidents at work by categories of work accidents and by economic activities CAEN Rev.2

\begin{tabular}{|c|c|c|c|c|c|c|}
\hline \multirow{2}{*}{$\begin{array}{c}\text { CAEN Rev.2 (activities of } \\
\text { national economy) }\end{array}$} & \multicolumn{7}{|c|}{ Mears } \\
\cline { 2 - 7 } & $\mathbf{2 0 0 8}$ & $\mathbf{2 0 0 9}$ & $\mathbf{2 0 1 0}$ & $\mathbf{2 0 1 1}$ & $\mathbf{2 0 1 2}$ & $\mathbf{2 0 1 3}$ \\
\cline { 2 - 8 } & 4953 & 3839 & 4040 & 3908 & 4083 & 3575 \\
\hline TOTAL & 352 & 353 & 307 & 249 & 213 & 160 \\
\hline B Extractive industries & 1930 & 1414 & 1521 & 1478 & 1471 & 1331 \\
\hline $\begin{array}{c}\text { C Manufacturing } \\
\text { industries }\end{array}$ & 355 & 269 & 306 & 285 & 311 & 314 \\
\hline H Transport and storage & 67 & 44 & 45 & 63 & 73 & 54 \\
\hline $\begin{array}{c}\text { M Professional, scientific } \\
\text { and technical activities }\end{array}$ & 9 & 4 & 24 & 9 & 15 & 18 \\
\hline S Other service activities & 9 & & & & \\
\hline (C) 1998 - 2015 Institutul national de statistica [2] & \multicolumn{7}{|c|}{ unit Number of people } \\
\hline
\end{tabular}

Table 4: Accidents at maintenance work

\begin{tabular}{|c|c|c|c|c|c|c|}
\hline \multirow{3}{*}{$\begin{array}{l}\text { CAEN Rev.2 (activities of } \\
\text { national economy) }\end{array}$} & \multicolumn{6}{|c|}{ Years } \\
\hline & \multicolumn{6}{|c|}{ Measure unit Number of people } \\
\hline & 2008 & 2009 & 2010 & 2011 & 2012 & 2013 \\
\hline TOTAL & 4953 & 3839 & 4040 & 3908 & 4083 & 3575 \\
\hline $\begin{array}{c}\text { B Extractive industries } \\
40 \%\end{array}$ & 141 & 141 & 123 & 100 & 85 & 64 \\
\hline $\begin{array}{c}\text { C Manufacturing } \\
\text { industries } 25 \%\end{array}$ & 483 & 354 & 380 & 370 & 368 & 333 \\
\hline $\begin{array}{c}\text { H Transport and storage } \\
20 \%\end{array}$ & 71 & 54 & 61 & 57 & 62 & 63 \\
\hline $\begin{array}{c}\text { M Professional, scientific } \\
\text { and technical activities } \\
15 \%\end{array}$ & 10 & 7 & 7 & 9 & 11 & 8 \\
\hline S Other service activities & 9 & 4 & 24 & 9 & 15 & 18 \\
\hline $\begin{array}{l}\text { Total accidents in } \\
\text { maintenance }\end{array}$ & 713 & 559 & 595 & 545 & 541 & 486 \\
\hline $\begin{array}{l}\text { Total accidents in } \\
\text { maintenance \% }\end{array}$ & 14,40 & 14,56 & 14,73 & 13,93 & 13,25 & 13,58 \\
\hline
\end{tabular}

The average for recorded accidents in the maintenance activities (percentage) for a period of six years from 2008 to 2013, reported at total number of accidents is 14,08\%. In the same time the average of percentage of workers involved in maintenance activities reported at total number of workers is $8,24 \%$. It easily finds a significant difference between these two values. At the same time comparing the rate of accidents in maintenance activities in Romania with similar values in other European countries (around $20 \%$ of all accidents in Belgium, in 2005-2006, were related to maintenance operations, as well as around 18-19\% in Finland, 14-17\% in Spain, and 10-14\% in Italy, in 2003-2006 [2]), it is found that there are not important differences.

\section{Analysis of the risks of accidents in maintenance activities}

Maintenance activities have in terms of occupational health and safety the risks of workstation where repairs or periodic maintenance is performed. In addition to these general risks can be mentioned a number of specific risks:

- the maintenance work is performed near a running technological process or are performed maintenance activities on machines and equipment's under operating process;

- for part of activities of maintenance cannot be provided textbooks or maintenance and repair instructions. So, are needed rapid technical solutions to ensure a high quality of intervention, safe in terms of health and safety;

- the risk of human error is higher than for routine works; 
- the working conditions often differ from typical and in some cases can reach the emergencies conditions;

- working under time pressure is another major risk and can be identified two types of time pressure:

o time pressure for repairs made to the machines and equipments that have accidental failures;

o time pressure for repairs made to the machines and equipments which are under preventive maintenance, pressure from production departments.

- the existence of physical risks due to weak engineering design of machines and equipment in terms of maintenance:

o accessibility cumbersome to faulty components;

o working in unusual positions;

- the existence of chemical risk due to some material which are not permitted for use (eg asbestos) in structure of equipments [1];

- the existence of biological risks, particularly in maintenance of purge systems;

- the existence of psychosocial risks:

o work on weekends and during holidays;

o irregular schedule.

\section{Conclusions}

Statistical analysis of occupational accidents occurred during the maintenance activities to the total number of occupational accidents, in Romania, 14.08\%, compared with the statistical analysis of the number of workers involved in the maintenance activities of the total number of active persons $8.24 \%$, showing a much higher rate of occurrence of accidents in maintenance work compared with number of maintenance workers. Values obtained are comparable to those in other EU countries.

Possible errors in these analyses are due to insufficient statistical breakdowns in terms of the two monitored parameters: number of workers involved in the maintenance work and work accidents in this area. To compensate this deficiency were made approximations based on the authors' experience.

Analysis of the risks of accidents in maintenance activities confirm the statistical analysis of accidents in maintenance work by highlighting, in addition to the general risks, another specific risks, some of them with high potential levels.

To reduce the level of risk, requirement imposed by law, it requires a proper assessment for each maintenance job, considering the great variety of industrial and non-industrial sectors in which it performs maintenance.

The assessment must be accompanied by programs to reduce the risks of any kind and the programs must include technical, organizational and economic measures. Among them should not miss:

- creating an integrated management system

- designing safer machines and equipment for maintenance workers not only for operators.

- the creation of specific skills and abilities maintenance workers

- effective communication

\section{References}

- Banica M., Şugar I.R., Experimental studies on reducing noise pollution and chemical pollution of motor vehicles, Proceedings of the 12th WSEAS international conference on Mathematics and computers in biology, business and acoustics, pp. 82-85, (2011).

- http://statistici.insse.ro/shop/

- https://osha.europa.eu/en/publications/factsheets/90/view 